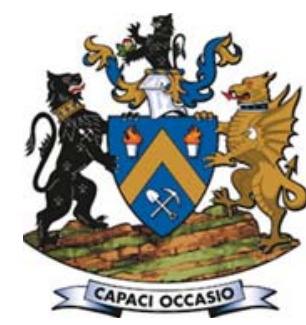

\title{
Matte - tap-hole clay - refractory brick interaction in a PGM smelter
}

\author{
by J. Du Toit*, R.D. Cromarty*, and A.M. Garbers-Craig* \\ Paper written on project work carried out in partial fulfilment of BEng (Metallurgical \\ Engineering)
}

\section{Synopsis}

Penetration of matte into tap-hole bricks causes detrimental refractory wear, which can lead to furnace breakouts. The ability of the tap-hole clay to form a protective layer on the brick, thereby limiting matte penetration was investigated by examining the interaction between platinum group metal (PGM) matte, tap-hole clay, and alumina-chrome refractory bricks on a laboratory scale.

Samples containing clay and brick as well as samples containing clay, brick, and matte were heated to different temperatures to establish the clay-brick interaction and the extent of matte penetration. The greatest degree of physical contact between the brick and clay was achieved at curing temperatures of $600^{\circ} \mathrm{C}$. Poor clay-brick contact was observed in the sample that was heated to $900^{\circ} \mathrm{C}$.

Matte displaced the clay in the clay-brick-matte sample that was heated to $1350^{\circ} \mathrm{C}$, with significant matte penetration into the brick. Less matte penetration was observed when the clay-brick-matte sample was heated to $1500^{\circ} \mathrm{C}$. Less matte penetration was also observed in the claybrick-matte sample in which the clay and brick were pre-baked at $800^{\circ} \mathrm{C}$, and the sample then reacted with matte at $1350^{\circ} \mathrm{C}$.

\section{Keywords}

tap-hole clay, alumina-chrome refractory bricks, PGM matte, reaction interface, penetration.
The amount and positioning of tap-hole clay in the tap-hole and tapping channel affect the shape and length of the tapping channel, which in turn affect the consistency that can be achieved in the tapping process (Nelson and Hundermark, 2014). Wear of the tap-hole and tapping channel results in less control being possible on the tapping process and less safe operating conditions due to the possibility of burn-through and unintentional reopening of the tap-hole. Worn refractories have to be replaced, requiring significant expenses and downtime (Nelson and Hundermark, 2014).

It is generally accepted that refractory wear by matte occurs in three steps. Penetration of the matte into the bricks occurs first. Penetration is followed by corrosion and erosion, during which the worn refractory bricks are corroded and pieces of brick are removed from the tapping channel along with molten material (Nelson and Hundermark, 2014). The extent of refractory wear depends on the amount of matte that penetrates into the brick and the temperature and viscosity of the matte. An increase in matte temperature leads to a decrease in matte viscosity and an associated increase in matte fluidity and ability to penetrate into the refractory brick (Nelson et al., 2005).

Brick wear may be minimized through protection provided by the tap-hole clay. Ideally, upon injection of the tap-hole clay into the tapping channel and tap hole, interaction between the tap-hole clay and brick would make matte penetration into the brick more difficult since matte would be required to move through the clay before penetration into the brick is possible. This interaction between taphole clay and brick and the associated extent of matte penetration formed the focus of this study.

* Department of Materials Science and Metallurgical Engineering, University of Pretoria.

(1) The Southern African Institute of Mining and Metallurgy, 2016. ISSN 2225-6253. Paper received Feb. 2016. 


\section{Matte - tap-hole clay - refractory brick interaction in a PGM smelter}

\section{Materials}

Primary PGM matte was obtained from the Anglo Platinum Polokwane smelter, while alumina-chrome bricks and taphole clay were obtained from the refractory suppliers to the Polokwane smelter ${ }^{1}$.

These materials were characterized using X-ray diffraction analysis (XRD), X-ray fluorescence (XRF), and scanning electron microscopy using energy-dispersive X-ray spectroscopy (SEM-EDS).

\section{PGM matte}

Quantitative XRD analysis indicated that the nickel-copperrich PGM matte consisted of $61.9 \%(\mathrm{Fe}, \mathrm{Ni})_{9} \mathrm{~S}_{8}, 13.3 \% \mathrm{FeS}$, 6.6\% $\mathrm{Cu}_{5} \mathrm{FeS}_{4}, 6.8 \% \mathrm{SiO}_{2}, 6 \% \mathrm{CaAl}_{2} \mathrm{Si}_{2} \mathrm{O}_{8}$, and $3.9 \% \mathrm{FeCr}_{2} \mathrm{O}_{4}$.

\section{Alumina-chrome refractory bricks}

XRF analysis confirmed that the brick contained $75 \% \mathrm{Al}_{2} \mathrm{O}_{3}$, $20.7 \% \mathrm{Cr}_{2} \mathrm{O}_{3}, 2.2 \% \mathrm{P}_{2} \mathrm{O}_{5}$, and $1 \% \mathrm{SiO}_{2}$. XRD analysis revealed that $\mathrm{Al}_{2} \mathrm{O}_{3}$ and the $(\mathrm{Al}, \mathrm{Cr})_{2} \mathrm{O}_{3}$ solid solution phase were the major phases present in the brick $(56.0 \%$ and $40.3 \%$ respectively), while trace amounts aluminium phosphate $\left(\mathrm{AlPO}_{4}\right)$ and cristobalite $\left(\mathrm{SiO}_{2}\right)$ could also be detected.

Microstructurally, the brick consisted of large alumina grains embedded in an alumina-chrome-based matrix, bonded through the formation of the $(\mathrm{Al}, \mathrm{Cr})_{2} \mathrm{O}_{3}$ solid solution phase (Figure 1).

\section{Tap-hole clay}

The tap-hole clay is an organically bound material. XRD analyses were conducted on the raw clay, and on clay samples that were heated to $950^{\circ} \mathrm{C}$ and subsequently cooled to room temperature in an oxidizing as well as an inert atmosphere.

The raw clay was found to consist largely of the crystalline phases corundum and andalusite $(55 \mathrm{wt} \%$ and $11 \mathrm{wt} \%$ respectively) with some silicon carbide, silicon, quartz, mullite, and a small amount of graphite. The carbon binder present in the clay is an amorphous phase which was not quantified by XRD analysis.

Upon heating, graphite is retained in the sample in an inert atmosphere but is oxidized from the system when heated in air.

In order to allow comparison between types and amounts of phases under oxidizing and inert atmospheric conditions, the analysis of the sample heated under inert atmosphere was normalized to exclude graphite. It was found that andalusite decomposes into mullite $\left(3 \mathrm{Al}_{2} \mathrm{O}_{3} \cdot 2 \mathrm{SiO}_{2}\right)$ and $\mathrm{SiO}_{2}$ or a glassy phase when heated in both the inert and oxidizing atmospheres. According to Schneider and Komarneni (2006), andalusite is stable up to temperatures in the vicinity of $780^{\circ} \mathrm{C}$, at which decomposition of andalusite into mullite and silica initiates (Schneider and Komarneni, 2006). The decrease in the amount of andalusite in the oxidizing and inert atmospheres is therefore expected with an associated increase in mullite and silica. This agrees with the findings of the XRD analysis, where mullite increased from $5.3 \%$ to almost $10 \%$ and silica from $6.9 \%$ to close to $10 \%$ in both samples.
Thermogravimetric analysis (TGA) was conducted on the tap-hole clay to establish the temperatures at which decomposition of the binder takes place (Figure 2). A 4\% decrease in mass was observed between 100 and $200^{\circ} \mathrm{C}$ when the sample was heated in both air and nitrogen. An additional $10 \%$ mass loss was observed at temperatures between 450 and $600^{\circ} \mathrm{C}$ in air. The mass loss between 100 and $200^{\circ} \mathrm{C}$ can be ascribed to volatiles being driven from the sample. Pérez et al. (2004), obtained similar results through thermogravimetric analysis of pitch binders. The $450-600^{\circ} \mathrm{C}$ temperature range correlates to the temperature range at which oxidation of graphite occurs (Xiaowei, Jean-Charles, and Suyuan, 2004). The sample heated in air underwent a large mass loss in the $450-600^{\circ} \mathrm{C}$ range due to graphite oxidation. The mass of the sample heated in nitrogen over this temperature range remained unchanged, indicating the completion of the pyrolysis of the binder.

\section{Experimental}

Laboratory-scale experiments were performed to simulate the clay-brick (CB) and the clay-brick-matte (CBM) interactions. In both sets of experiments argon gas was used for purging to avoid the oxidation of sulphur in the matte.

For the clay-brick interaction a Phasecon tube furnace was used. The furnace was heated to temperatures of $600^{\circ} \mathrm{C}$ and $900^{\circ} \mathrm{C}$ and kept at temperature for one hour. A heating ramp rate of $15^{\circ} \mathrm{C} / \mathrm{min}$ was used upon heating and $50^{\circ} \mathrm{C} / \mathrm{min}$ upon cooling. Technical-grade argon (99.9\% argon) was used to purge the furnace for the heating, dwell, and cooling periods.

In the clay-brick experiment an alumina crucible assembly, containing a brick core surrounded by clay, was used (Figure 3).

The clay-brick-matte experiments were done using an induction furnace with a graphite susceptor in an insulated gas-tight chamber. An Ambrell Ekoheat power supply was used and temperature was controlled using a Eurotherm temperature controller and a type B thermocouple.

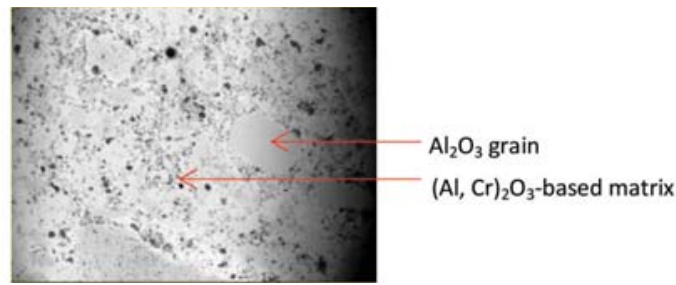

Figure 1-Backscattered electron image of as-received brick

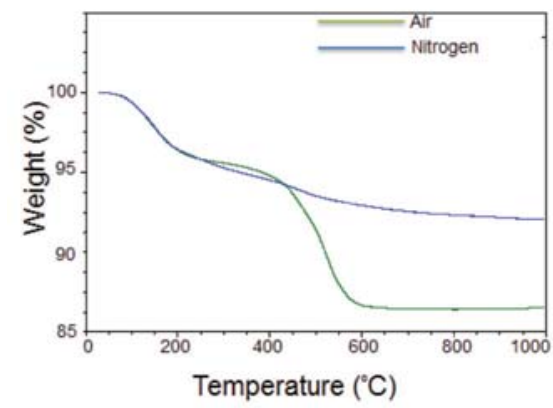

Figure 2-Tap-hole clay TGA results 


\section{Matte - tap-hole clay - refractory brick interaction in a PGM smelter}

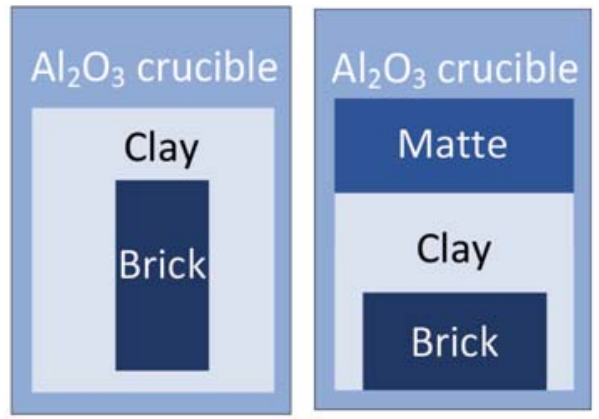

Figure 3-CB-interaction crucible design (left) and CBM-interaction crucible design (right)

The induction furnace was purged with technical-grade argon for 30 minutes prior to heating to temperatures of $1350^{\circ} \mathrm{C}$ and $1500^{\circ} \mathrm{C}$. Purging continued for the duration of the experiment. A heating rate of $20^{\circ} \mathrm{C} / \mathrm{min}$ was used, followed by dwelling at temperature for 60 minutes and then cooling at a rate of $50^{\circ} \mathrm{C} / \mathrm{min}$.

The crucible assembly consisted of an alumina crucible with a section of the brick placed at the bottom and clay added to the top and around the sides of the brick. Matte was then added on top of the clay (Figure 3).

An additional experiment was performed in which the CBM set-up was modified by first baking the clay and brick in an alumina crucible in the Phasecon retort furnace at $800^{\circ} \mathrm{C}$ for one hour. After cooling, the matte was added and the CBM experiment was performed in the induction furnace as described previously. The purpose of this experiment was to establish whether pre-baking would increase the physical contact and extent of interaction between the clay and brick, thereby improving the resistance against matte penetration.

The samples were sectioned, and polished samples prepared for analysis on completion of the CB and CBM experiments. Reflected light microscopy and SEM-EDS analysis were used to determine the amount of clay-brick interaction as well as the extent of matte penetration.

\section{Results and discussion}

\section{Clay-brick interaction}

The clay-brick interaction was limited, as areas at the claybrick interface could be distinguished where no direct contact occurred. Areas of poorer and better physical contact were observed, with overall better contact being achieved in the sample heated to $600^{\circ} \mathrm{C}$ (Figure 4), compared to the sample that was heated to $900^{\circ} \mathrm{C}$ (Figure 5). The gap between the clay and brick implies that chemical interaction did not occur.

\section{Clay-brick-matte interaction}

The reflected light microscopy images of the samples containing clay, brick, and matte indicate that matte (brightly coloured) penetrated into both the clay (Figure 6A) and the brick (Figure 6B).

In the $\mathrm{CBM}$ sample heated to $1350^{\circ} \mathrm{C}$, the matte seemed to have displaced the clay. The top layer, which initially consisted of matte, contained clay (dark grey, Figure 7A), while the section above the brick, which was initially clay, contained matte only (light grey, Figure 7B). Copper sulphide (light sulphide phase) and an iron sulphide (dark sulphide phase) could be distinguished in the solidified matte (Figure 7B), while an Fe-Ni-Cu-based alloy could also be observed.

The brick (Figure 7C) was also penetrated by the matte. This was expected, since the matte displaced the clay and no protective layer was present to resist matte penetration into the brick.

The sample heated to $1500^{\circ} \mathrm{C}$ also showed significant matte penetration; although complete displacement of the clay section with matte was not evident. There is a clear distinction between the initial matte section (light grey) and the initial clay section (dark grey), although droplets of matte seem to have penetrated into the clay region (Figure 8A). The bright phases in the clay are alloy droplets and not matte. Alloy droplets, however, were not observed in the brick, but only matte droplets.

Greater interaction between the clay and the brick was observed in the $1350^{\circ} \mathrm{C} \mathrm{CBM}$ sample that contained prebaked clay. There was, however, still matte penetration into the clay and the brick sections (Figure 9).

\section{Conclusions}

Decomposition of the binder occurs at temperatures up to $600^{\circ} \mathrm{C}$ with volatiles being driven off in the $100-200^{\circ} \mathrm{C}$ temperature range. Oxidation of graphite occurs at $450-600^{\circ} \mathrm{C}$.

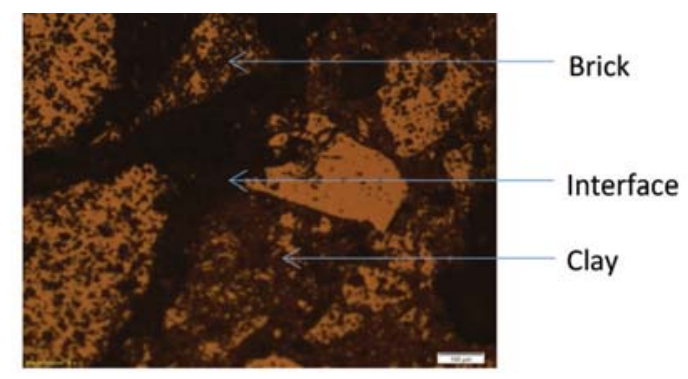

Figure 4-Reflected light micrograph of clay-brick interaction at $600^{\circ} \mathrm{C}$

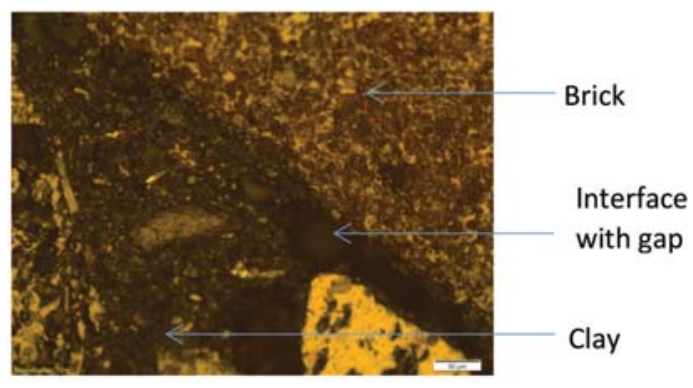

Figure 5-Reflected light micrograph of clay-brick interaction at $900^{\circ} \mathrm{C}$
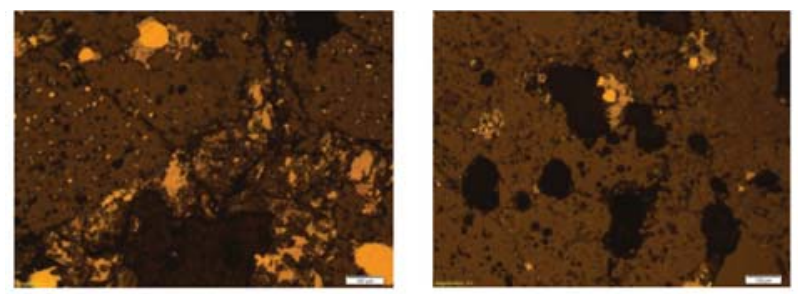

Figure 6-Reflected light micrographs of sample heated to $1350^{\circ} \mathrm{C}$. (A) Clay section of the sample and (B) brick section of the sample 


\section{Matte - tap-hole clay - refractory brick interaction in a PGM smelter}
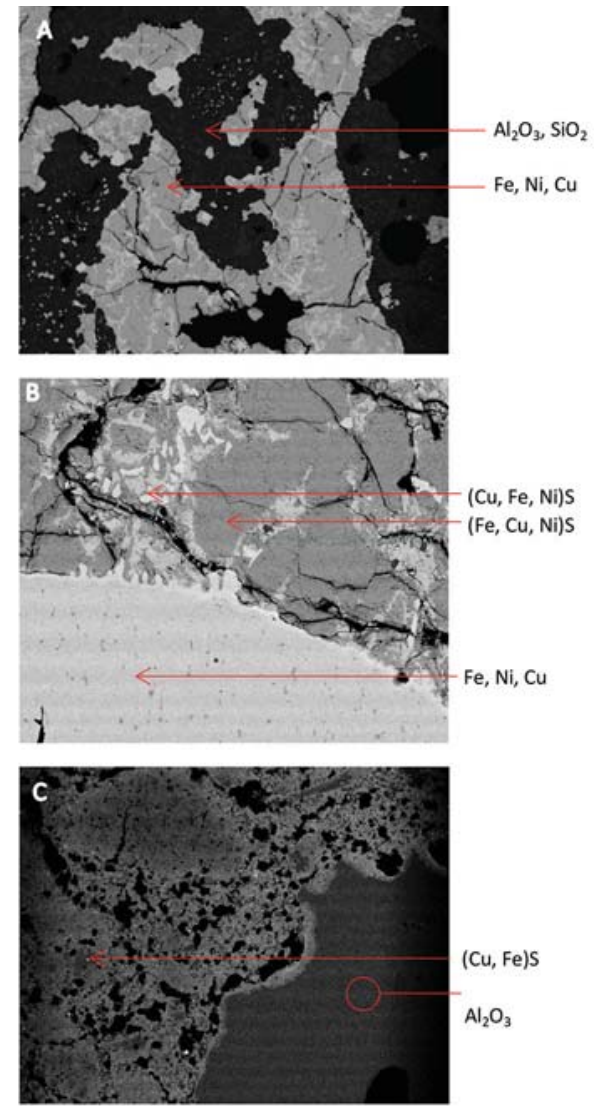

Figure 7-Backscattered electron images of the CBM sample heated to $1350^{\circ} \mathrm{C}$. (A) Initial matte region, (B) initial clay region, (C) initial brick region
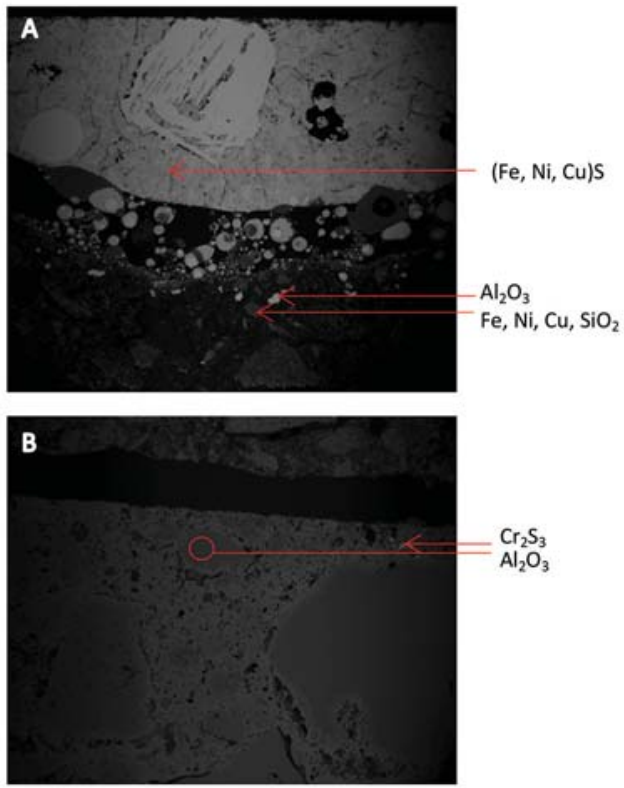

Figure 8-Backscattered electron image of the CBM sample heated to $1500^{\circ} \mathrm{C}$. (A) (Initial matte and clay regions, (B) initial brick region

Interaction between tap-hole clay and brick does not occur extensively at either $600^{\circ} \mathrm{C}$ or $900^{\circ} \mathrm{C}$. Regions of poor physical contact between the clay and brick were observed.

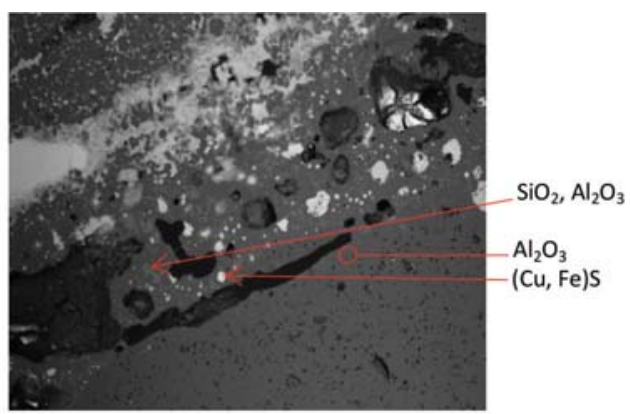

Figure 9-Backscattered electron image of the CBM sample heated to $1350^{\circ} \mathrm{C}$ after pre-baking at $800^{\circ} \mathrm{C}$ - initial clay-brick interface region

Without physical contact, chemical interaction could also not occur. Without clay-brick interaction, the clay provides little protection against matte penetration into the brick. The physical contact between the clay and the brick proved to be better when the clay and brick were reacted at a lower temperature $\left(600^{\circ} \mathrm{C}\right)$, rather than a higher temperature $\left(900^{\circ} \mathrm{C}\right)$.

Matte penetrated through the clay and into the brick in samples heated to $1350^{\circ} \mathrm{C}$ as well as to $1500^{\circ} \mathrm{C}$. Less matte penetration occurred in the $1500^{\circ} \mathrm{C}$ sample and the $1350^{\circ} \mathrm{C}$ sample that contained pre-baked tap-hole clay.

In the $\mathrm{CBM}$ sample that was reacted at $1500^{\circ} \mathrm{C}$, matte reacted with the tap-hole clay to form a $\mathrm{Cu}-\mathrm{Fe}-\mathrm{Ni}$ alloy.

\section{Acknowledgements}

The authors would like to thank Anglo American (Dr Lloyd Nelson, Rodney Hundermark, and Keith Hines) for supplying the raw materials as well as for technical assistance. A word of thanks also goes to colleagues and analytical staff in the Department of Material Science and Metallurgical Engineering at the University of Pretoria.

\section{References}

Hundermark, R., De Villiers, B., and Ndlovu, J. 2006. Process description and short history of Polokwane Smelter. Southern African Pyrometallurgy 2006. Jones, R.T. (ed.). Southern African Institute of Mining and Metallurgy, Johannesburg. pp. 35-41.

Nelson, L.R. and Hundermark, R.J. 2014. 'The tap-hole'- key to furnace performance. Furnace Tapping Conference 2014. Southern African Institute of Mining and Metallurgy, Johannesburg. pp. 1-32.

Nelson, L.R., Stober, F., Ndlovu, J., De Villiers, L.P., and Wanblad, D. 2005. Role of technical innovation delivery at the Polokwane Smelter. Nickel and Cobalt 2005. Challenges in Extraction and Production, Calgary. Donald, J. and Schonewille, R. (eds.). CIM, Montreal. pp. 91-116.

Perez, M., Granda, M.S., Morgan, T., and Menendez, R. 2004. A thermoanalytical study of the co-pyrolysis of coal-tar pitch and petroleum pitch. Fuel, vol. 83, no. 9. pp. 1257-1265.

SchneIDER, H. and Komarneni, S. 2006. Mullite. Wiley, Weinham.

XIAoweI, L., JEAn-Charles, R., and SuYuAn, Y. 2004. Effect of temperature on graphite oxidation behaviour. Nuclear Engineering and Design, pp. 273-280. 